\title{
Article \\ Searching for Biological Function of the Mysterious PA2504 Protein from Pseudomonas aeruginosa
}

\author{
Joanna Drabinska *, Kamil Steczkiewicz (1), Martyna Kujawa and Elżbieta Kraszewska * \\ Institute of Biochemistry and Biophysics PAS, Pawińskiego 5a, 02-106 Warsaw, Poland; ksteczk@ibb.waw.pl (K.S.); \\ martyna.kujawa@yahoo.pl (M.K.) \\ * Correspondence: j.drabinska@ibb.waw.pl (J.D.); elzbietak@ibb.waw.pl (E.K.)
}

check for updates

Citation: Drabinska, J.; Steczkiewicz,

K.; Kujawa, M.; Kraszewska, E.

Searching for Biological Function of the Mysterious PA2504 Protein from Pseudomonas aeruginosa. Int. J. Mol. Sci. 2021, 22, 9833. https://doi.org/ $10.3390 /$ ijms 22189833

Academic Editor: Giordano Rampioni

Received: 26 August 2021

Accepted: 9 September 2021

Published: 11 September 2021

Publisher's Note: MDPI stays neutral with regard to jurisdictional claims in published maps and institutional affiliations.

Copyright: (C) 2021 by the authors Licensee MDPI, Basel, Switzerland. This article is an open access article distributed under the terms and conditions of the Creative Commons Attribution (CC BY) license (https:// creativecommons.org/licenses/by/ $4.0 /)$.

\begin{abstract}
For nearly half of the proteome of an important pathogen, Pseudomonas aeruginosa, the function has not yet been recognised. Here, we characterise one such mysterious protein PA2504, originally isolated by us as a sole partner of the RppH RNA hydrolase involved in transcription regulation of multiple genes. This study aims at elucidating details of PA2504 function and discussing its implications for bacterial biology. We show that PA2504 forms homodimers and is evenly distributed in the cytoplasm of bacterial cells. Molecular modelling identified the presence of a Tudor-like domain in PA2504. Transcriptomic analysis of a $\triangle P A 2504$ mutant showed that 42 transcripts, mainly coding for proteins involved in sulphur metabolism, were affected by the lack of PA2504. In vivo crosslinking of cellular proteins in the exponential and stationary phase of growth revealed several polypeptides that bound to PA2504 exclusively in the stationary phase. Mass spectrometry analysis identified them as the $30 \mathrm{~S}$ ribosomal protein S4, the translation elongation factor TufA, and the global response regulator GacA. These results indicate that PA2504 may function as a tether for several important cellular factors.
\end{abstract}

Keywords: PA2504; TUDOR domain; Pseudomonas aeruginosa; sulphur metabolism; crosslink in vivo; RppH; RNA-Seq; Nudix

\section{Introduction}

Pseudomonas aeruginosa is a Gram-negative bacterium widespread in the environment. Due to its high adaptive abilities, regulated by many poorly characterised mechanisms, it can colonise and infect diverse organisms. This pathogen is commonly present in the hospital environment, where it imposes a great threat to immunocompromised patients, especially those of the chirurgic, intensive care, and neonatal units (reviewed by Spagnolo and colleagues [1]).

Both the cell cycle and virulence of $P$. aeruginosa are dependent on a variety of factors of which secretion systems, quorum sensing, biofilm formation, motility and toxin production have been widely studied (reviewed by Jimenez and colleagues [2]). Despite this, our understanding of these and other processes of $P$. aeruginosa is certainly incomplete. Taking into consideration that almost half of the proteins encoded by its genome still lack annotated function [3], the question arises of which proteins are involved in the processes abovementioned.

When studying the Nudix type RppH hydrolase of $P$. aeruginosa, we observed that its only partner was the previously uncharacterised protein PA2504.

In E. coli, RppH catalyses the removal of pyrophosphate from 5'-triphosphorylated RNA transcripts and via participation in RNA decay regulates expression of different genes [4]. It was later observed that $\mathrm{RppH}$ of $P$. aeruginosa can functionally substitute for $\mathrm{RppH}$ in $E$. coli cells, indicating that, similar to its counterpart, it could also mediate RNA turnover in vivo. The main phenotypic change caused by the absence of $\mathrm{RppH}$ in $P$. aeruginosa was a significant increase in the level of the major virulence factor pyocyanin [5]. 
Up to now, the biological function of PA2504 has not been studied, but it has been observed by different authors that the level of PA2504 transcript changed visibly depending on the conditions of bacterial growth (Table 1).

Table 1. Cellular level of PA2504 transcript in different conditions of bacterial growth. Listed are the conditions from which the samples were withdrawn, the P. aeruginosa strains used for the experiment (Strain), fold change of PA2504 gene expression (FC), and source of the data.

\begin{tabular}{cccc}
\hline Conditions & Strain & FC & Source \\
\hline Burn wound isolate (human) vs. stationary growth in rich liquid medium & clinical isolate & -11.0 & {$[6]$} \\
\hline Cystic fibrosis patient lung isolate vs. stationary growth in rich liquid medium & clinical isolate & -9.0 & {$[6]$} \\
\hline$\Delta v q s R$ vs. WT, ABC minimal medium & PAO1 & +8.0 & {$[7]$} \\
\hline Murine tumour isolate (mouse) vs. stationary growth phase in rich liquid medium & veterinary isolate & -6.3 & {$[6]$} \\
\hline GUN (glucose uptake null) + glucose vs. WT & PAO1 & +3.6 & {$[8]$} \\
\hline GUN (glucose uptake null) + glucose vs. WT + glucose & PAO1 & +2.8 & {$[8]$} \\
\hline
\end{tabular}

To elucidate the physiological role of PA2504 in P. aeruginosa, we applied a number of techniques including phenotypic analysis of a PA2504 null mutant and RNA sequencing, in vivo protein crosslinking with mass-spectrometry, and protein structure modelling. We found that the PA2504 homodimer wasevenly distributed in the cytoplasm and most probably serves as an assembly platform for several cellular proteins including TufA (PA4265), S4 protein (PA4239), and GacA (PA2586).

\section{Results}

\subsection{Phenotypic Characteristic of PA2504 Mutants}

Recently, using a P. aeruginosa two-hybrid system library [9] and the one-to-one bacterial two-hybrid method (BACTH), we found PA2504 to be the sole partner of the RppH Nudix hydrolase (Figure S3, Supplementary Materials), earlier shown to function as a global regulator influencing many of transcripts including those involved in P. aeruginosa virulence [5]. This finding turned our attention to this uncharacterised PA2504 protein.

To establish the influence of PA2504 protein on P. aeruginosa functioning, cells carrying chromosomal deletion or overexpressing the PA2504 gene were investigated. To test the effect of the lack of PA2504 protein, the entire PA2504 gene was deleted using pAKE600 suicide vector and overexpression was conducted from an inducible arabinose promoter in the pKGB as described in the Materials and Methods. Single bacterial colonies of each mutant were transferred into L-broth or M9 minimal medium and growth was monitored. No major differences in the growth rate were observed between the mutants and the parental strain in either the exponential or stationary phase. (Figure S2a, Supplementary Materials).

Furthermore, the lack of PA2504 did not affect bacterial biofilm formation, motility, and the response to any tested antibiotics compared to the parental strain (Figure S2b-d, Supplementary Materials). These results indicate that PA2504 protein had no significant influence on the tested bacterial features.

We have previously shown that RppH influences pyocyanin production in P. aeruginosa [5]. To see whether PA2504 is also important in this process, the level of pyocyanin was determined in $\triangle P A 2504, \triangle r p p H$, and $\triangle P A 2504 \Delta r p p H$ mutants. In $\triangle P A 2504$, the pyocyanin production was the same as in the parental strain, and in the double mutant, it was similar to that of the single $\triangle r p p H$ mutant, indicating that the lack of PA2504 did not affected the $\mathrm{RppH}$ activity in pyocyanin production (Figure 1). 


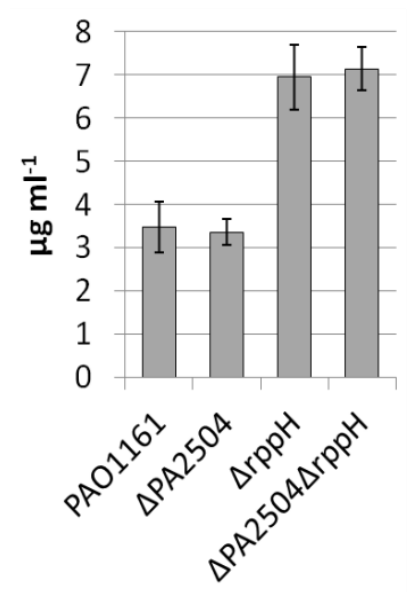

Figure 1. Pyocyanin production by P. aeruginosa strains at the stationary phase of growth. Determined as in the "Materials and Methods". Mean value of at least three independent replicates \pm SD is shown.

\subsection{Structural Studies of PA2504 Protein}

Since no indications pointing to a possible cellular function of PA2504 appeared from the phenotypic analysis of the mutants, molecular modelling of the protein was performed to search for specific domains in PA2504.

The PA2504 protein contains two domains: N-terminal DUF2314 (PF10077) and C-terminal DUF2185 (PF09951), both found almost exclusively in bacteria (Firmicutes, Proteobacteria, and many other unclassified bacterial species) and having no known function. According to the Pfam protein families database, the DUF2314-DUF2185 domain tandem is present in multiple Firmicutes (Bacillales) and Proteobacteria (Alphaproteobacteria, Gammaproteobacteria, and Burkholderiales).

Hhsearch detected a remote sequence similarity between the N-terminal domain of PA2504 and the TUDOR-like domain of a hypothetical protein from Neisseria gonorrhoeae (pdb | 5ueb, no publication available) with the score of 34.88 and an estimated probability of $93 \%$. This result was confirmed by the TrRosetta modelling framework, which provided consistent results with a confidence score of 0.71 for the full-length PA2504 (Figure 2a and Figure S4, Supplementary Materials). The C-terminal domain of PA2504 displayed no detectable sequence similarity to any protein of known structure or function. Additionally, the model provided by TrRosetta for this domain was not similar to any protein of known structure, suggesting that it could represent a novel protein fold.

TUDOR domains are widely recognised for their ability to bind modified amino acid residues like methylated lysine within a structure called an aromatic cage-a pocket formed by aromatic residues (Figure 2c). In this manner, they recognise methylated histones (e.g., ZMYND8 (pdb | 4cos) [10] and PHF1 (pdb | 5xfo) [11]) for gene expression regulation, or bind to other proteins (e.g., PHF20 (pdb |3p8d) [12] binding p53) and protecting it from ubiquitination and, as aconsequence, from degradation or Fragile $\mathrm{X}$ mental retardation protein (FMRP) interacting with both tri-methylated lysine and with 82-FIP, one of the FMRP nuclear partners $[13,14]$. Interestingly, unlike other histone-binding proteins, the model of PA2504 lacked extensive positively charged patches (Figure S5, Supplementary Materials). Overall, it was negatively charged with only a positively charged cleft between the N-terminal TUDOR-like and C-terminal domains (blue area in Figure S5, Supplementary Materials). 


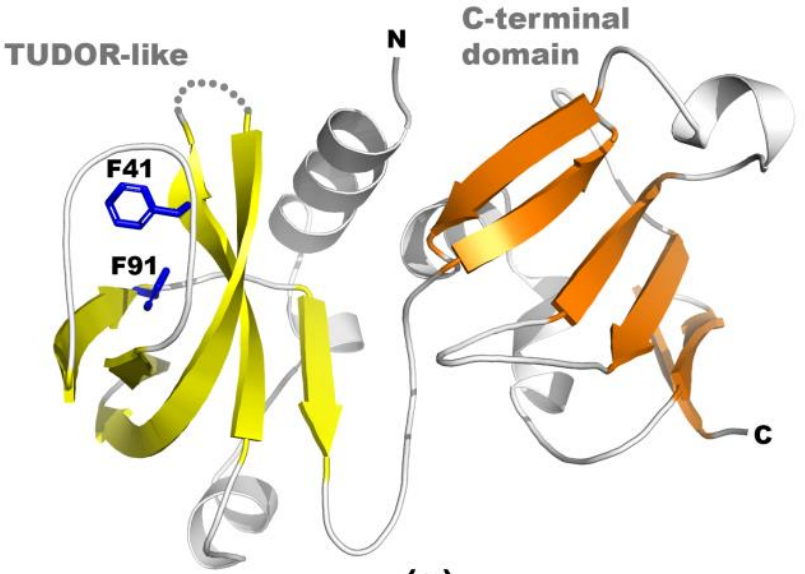

(a)
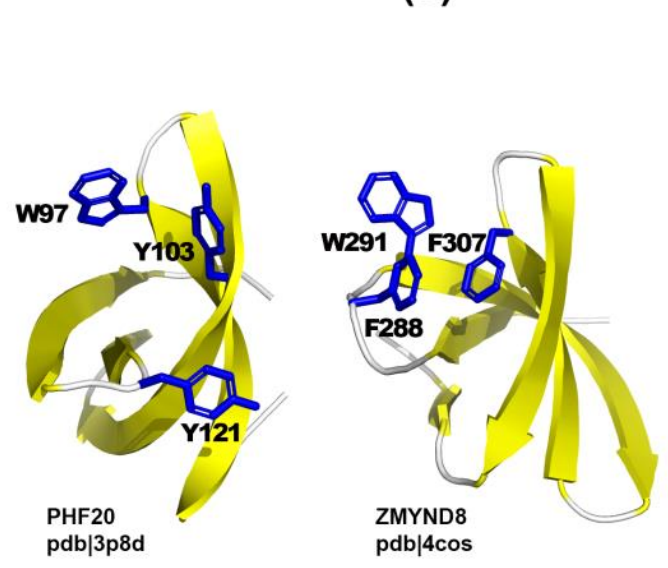

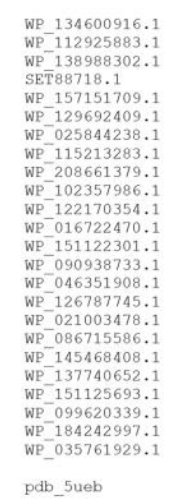

pdb_5ueb

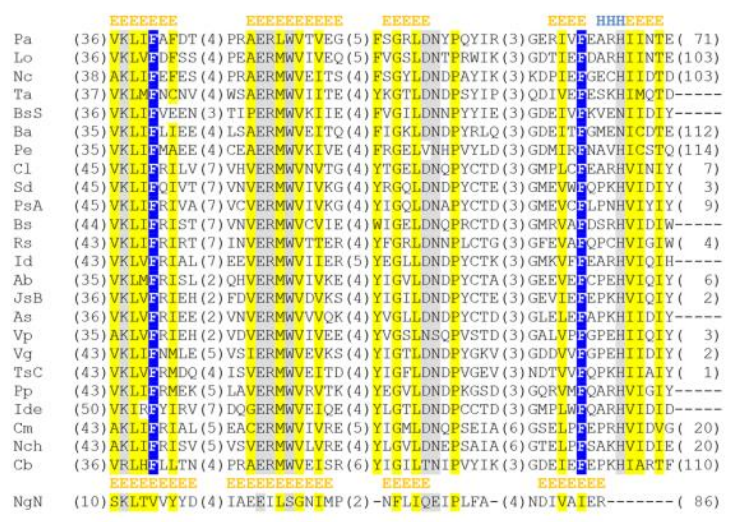

(b)
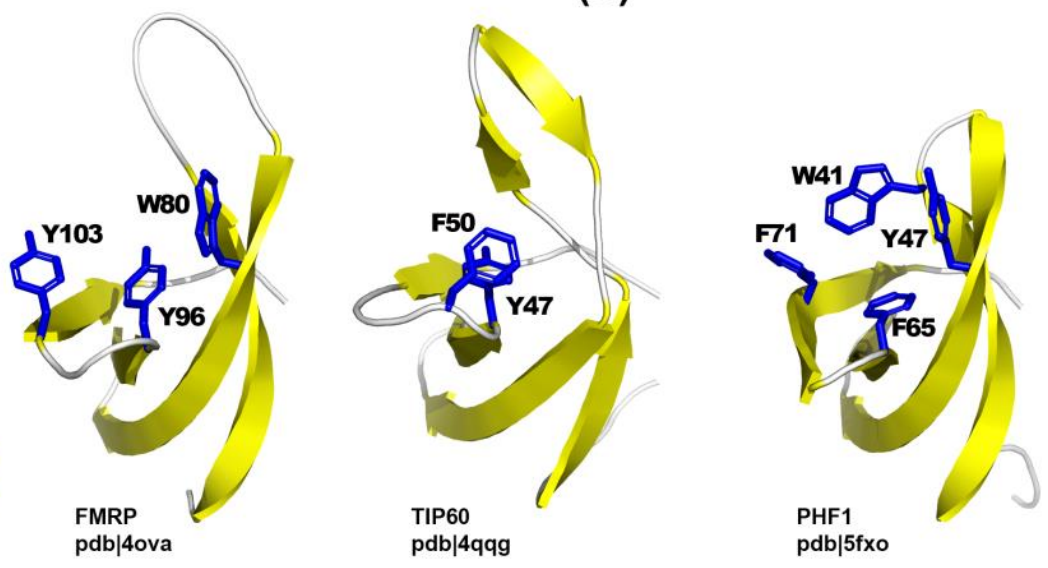

(c)

Figure 2. PA2405 contains N-terminal TUDOR-like domain and C-terminal domain of unknown function. (a) 3D model of PA2504; $\beta$-strands of TUDOR-like and C-terminal domains are in yellow and orange, respectively. Residues forming potential aromatic cage for ligand binding are shownas stick models and coloured blue. (b) Multiple sequence to structure alignment of PA2504 homologs and hypothetical protein from N. gonorrhoeae of known structure. Residue character conservation marked as follows: uncharged highlighted in yellow, polar in grey, and conserved aromatic residues in blue. Secondary structure predicted for PA2504 and found in the PDB structure are given above the corresponding regions. The number of residues omitted from the alignment is provided in parentheses. (c) 3D structures of other TUDOR-like proteins in an orientation corresponding to the PA2504 model in (a) (discussed in text).

\subsection{Oligomerisation of PA2504}

To check whether PA2504 is monomeric or forms higher order structures, we investigated its ability to form homo-interactions in vivo using the BACTH system and determined the size of purified PA2504 in solution by size exclusion chromatography combined with multi-angle light scattering (SEC-MALS). Figure 3 shows that PA2504 can oligomerise in vivo and that its SEC-MALS profile corresponds to that of a dimer. In conclusion, it is most likely that PA2504 is also a homodimer in vivo. 


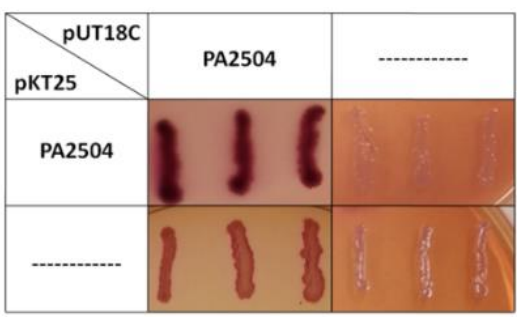

(a)

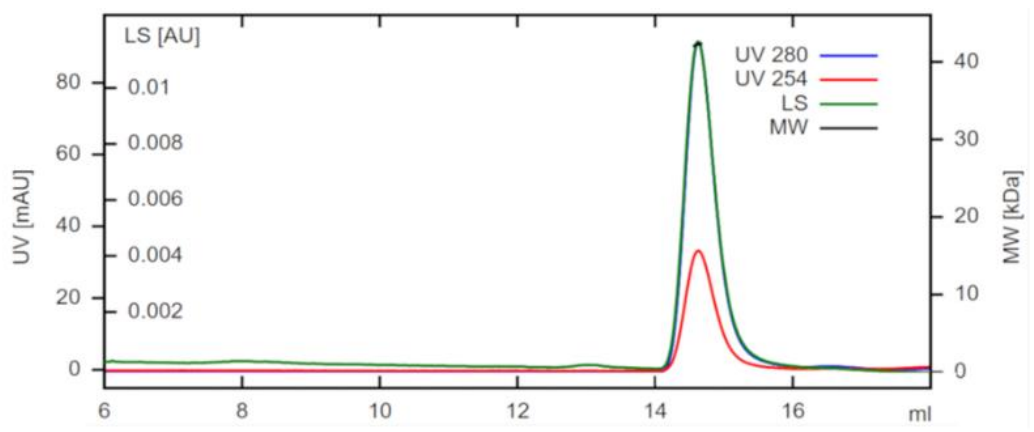

(b)

Figure 3. Dimerisation of PA2504 protein. (a) Interaction between monomeric forms of PA2504 visualised on MacConkey selective medium (red colonies). (b) SEC-MALS analysis of recombinant PA2504 protein. Purified protein was analysed on a Superdex 200 column combined with the light scattering instrument HELEOS as described in the Materials and Methods. LS—light scattering, MW-molecular weight.

\subsection{Cellular Localisation of PA2504}

To localise PA2504 in the cell, GFP tagged PA2504 was expressed in P. aeruginosa and observed under a fluorescence microscope. As seen in Figure 4, PA2504 did not associate with any particular cellular structure and was evenly distributed throughout the cells.

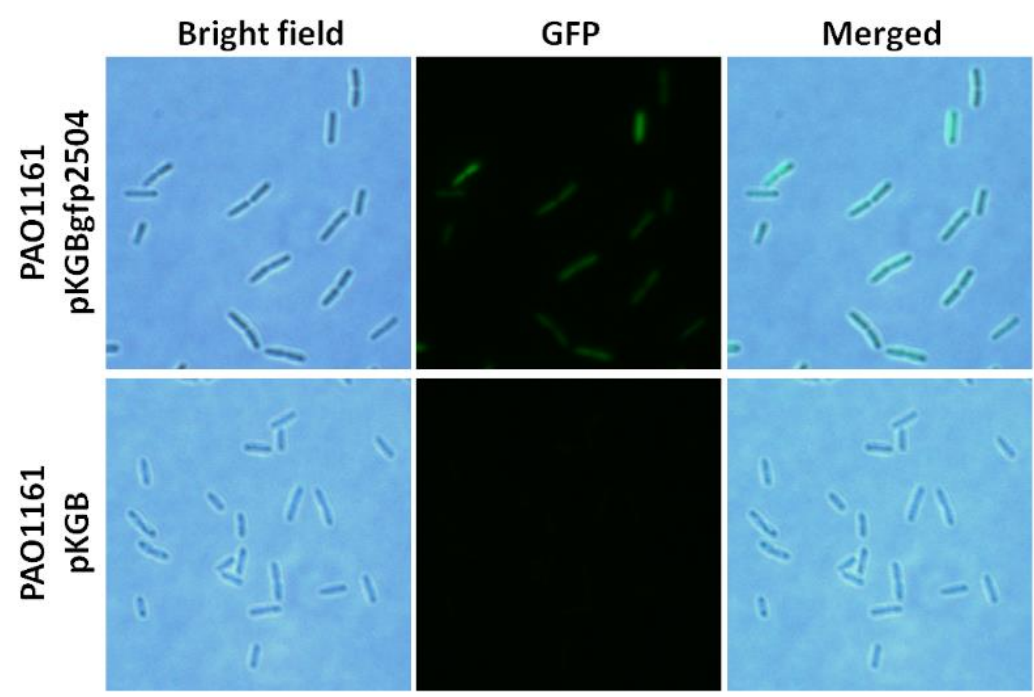

Figure 4. Localisation of GFP-PA2504 protein in P. aeruginosa cells. Bright field, GFP fluorescence, and merged are shown. The cells were visualised under a Zeiss Imager. M2 fluorescence microscope as described in theMaterials and Methods.

\subsection{Transcriptomic Analysis of $\triangle P A 2504$ Mutant}

Since our preliminary analyses failed to indicate a biological function for PA2504, we compared the transcriptomes of the $\triangle P A 2504$ and the wild-type PAO1161 strains using high-throughput RNA sequencing (RNA-Seq). Since it was found that the level of the PA2504 transcript was significantly higher (fold change $=6.81$ ) in the stationary phase than in the exponential phase of growth (Figure 5), we compared the transcriptomes in the stationary phase of growth. 


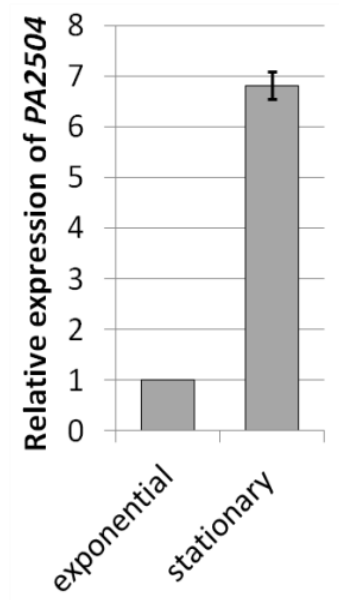

Figure 5. Expression of the P. aeruginosa PA2504 gene. PA2504 mRNA was quantified by RT-qPCR in exponential and stationary phase cultures of wild-type P. aeruginosa PAO1161 against nadB mRNA used as the reference. The relative expression level in the exponential phase was taken as 1 . Mean value of three independent replicates $\pm S E$ is shown.

The lack of the PA2504 protein affected the level of 42 transcripts, of which $41(97.6 \%)$ were downregulated. Notably, 30 differentially expressed genes $(71.4 \%)$ were related to sulphur assimilation and metabolism (Table 2, Figure 6).

Table 2. Transcripts differentially expressed in $\triangle P A 2504$.

\begin{tabular}{|c|c|c|c|}
\hline Gene ID & Name & $\log _{2}$ FC & Product Description \\
\hline PA0280 & cys $A$ & -2.70 & Sulphatethiosulphate $\mathrm{ABC}$ transporter ATP-binding protein CysA \\
\hline PA0281 & cysW & -2.76 & Sulphate transporter CysW \\
\hline PA0282 & cys T & -2.79 & Sulphate transporter CysT \\
\hline PA0283 & $s b p$ & -3.13 & Sulphate-binding protein \\
\hline PA0284 & $\operatorname{osc} A$ & -3.11 & Hypothetical protein/sulphur starvation response protein \\
\hline PA0399 & PA0399 & -0.73 & Cystathionine beta-synthase \\
\hline PA0400 & PA0400 & -0.54 & Cystathionine gamma-lyase \\
\hline PA1245 & $\operatorname{aprX}$ & -0.92 & Extracellular protease AprX \\
\hline PA1246 & $\operatorname{aprD}$ & -0.70 & Alkaline protease secretion ATP-binding protein AprD \\
\hline PA1247 & aprE & -0.64 & Alkaline protease secretion protein AprE \\
\hline PA1248 & $\operatorname{aprF}$ & -0.73 & Alkaline protease secretion protein AprF \\
\hline PA1249 & aprA & -0.83 & Alkaline metalloproteinase \\
\hline PA1493 & cys $P$ & -0.55 & Sulphate ABC transporter substrate-binding protein \\
\hline PA1756 & cys $H$ & -0.98 & Phosphoadenosinephosphosulphate reductase \\
\hline PA1837 & PA1837 & -1.52 & Hypothetical protein/oxidoreductase probably involved in sulphite reduction \\
\hline PA1838 & cysI & -1.29 & Sulphite reductase \\
\hline PA1912 & femI & -0.39 & ECF sigma factor FemI \\
\hline PA2062 & PA2062 & -1.00 & $\begin{array}{l}\text { Probable pyridoxal-phosphate dependent protein/IscS subfamily cysteine } \\
\text { desulphurase }\end{array}$ \\
\hline PA2086 & PA2086 & -1.12 & Epoxide hydrolase \\
\hline PA2202 & PA2202 & -1.79 & Amino acid permease \\
\hline PA2203 & PA2203 & -2.32 & Amino acid permease \\
\hline
\end{tabular}


Table 2. Cont.

\begin{tabular}{|c|c|c|c|}
\hline Gene ID & Name & $\log _{2}$ FC & Product Description \\
\hline PA2204 & PA2204 & -3.02 & ABC transporter \\
\hline PA2328 & PA2328 & -0.86 & Hypothetical protein/nitrate transport protein NrtA precursor \\
\hline PA2329 & PA2329 & -0.72 & $\begin{array}{c}\text { ABC transporter ATP-binding protein/nitrate/sulphonate/bicarbonate ABC } \\
\text { transporter ATPase }\end{array}$ \\
\hline PA2330 & PA2330 & -0.74 & Hypothetical protein/acyl-CoA/acyl-ACP dehydrogenase \\
\hline PA2426 & pvdS & -0.43 & Extracytoplasmic-function sigma-70 factor \\
\hline PA2481 & PA2481 & +0.46 & Hypothetical protein/thiosulphate dehydrogenase \\
\hline PA2594 & PA2594 & -1.40 & Putative periplasmic aliphatic sulphonate binding protein \\
\hline PA2598 & PA2598 & -0.70 & Hypothetical protein/methanesulphonate monooxygenase \\
\hline PA2786 & PA2786 & -1.10 & Hypothetical protein/GAF domain-containing protein \\
\hline PA3441 & ssuF & -3.07 & Molybdopterin-binding protein/organosulphonate utilisation protein SsuF \\
\hline PA3931 & PA3931 & -2.58 & Putative methionine-binding protein \\
\hline PA3932 & PA3932 & -0.97 & Transcriptional regulator \\
\hline PA4067 & oprG & -0.49 & Outer membrane protein OprG \\
\hline PA4195 & PA4195 & -1.64 & $\begin{array}{c}\text { Putative amino acid } \mathrm{ABC} \text { transporter substrate-binding protein } / A B C \\
\text { transporter glutamine-binding protein } \mathrm{GlnH} \text { precursor }\end{array}$ \\
\hline PA4442 & cysN & -1.87 & Bifunctional sulphate adenylyltransferase subunit 1 /adenylylsulphate kinase \\
\hline PA4443 & cys $D$ & -2.22 & Sulphate adenylyltransferase subunit 2 \\
\hline PA4470 & fumC1 & -0.29 & Fumarate hydratase \\
\hline PA4471 & PA4471 & -0.58 & Hypothetical protein \\
\hline PA5024 & $y \operatorname{tn} M$ & -0.44 & Hypothetical protein/sulphite exporter TauE/SafE \\
\hline PA5025 & metY & -0.62 & O-acetylhomoserineaminocarboxypropyltransferase \\
\hline PA5103 & puuR & -1.03 & Hypothetical protein/PhnD/SsuA/transferrin family substrate-binding protein \\
\hline
\end{tabular}

Listed are transcripts with the $\log _{2}$ fold change (FC) (differences statistically significant; with FDR-adjusted $p \leq 0.05$ ). In bold-genes related to sulphur metabolism. In italics are descriptions of close homologs of $P$. aeruginosa genes identified using the BLASTP ${ }^{\circledR}$ program.

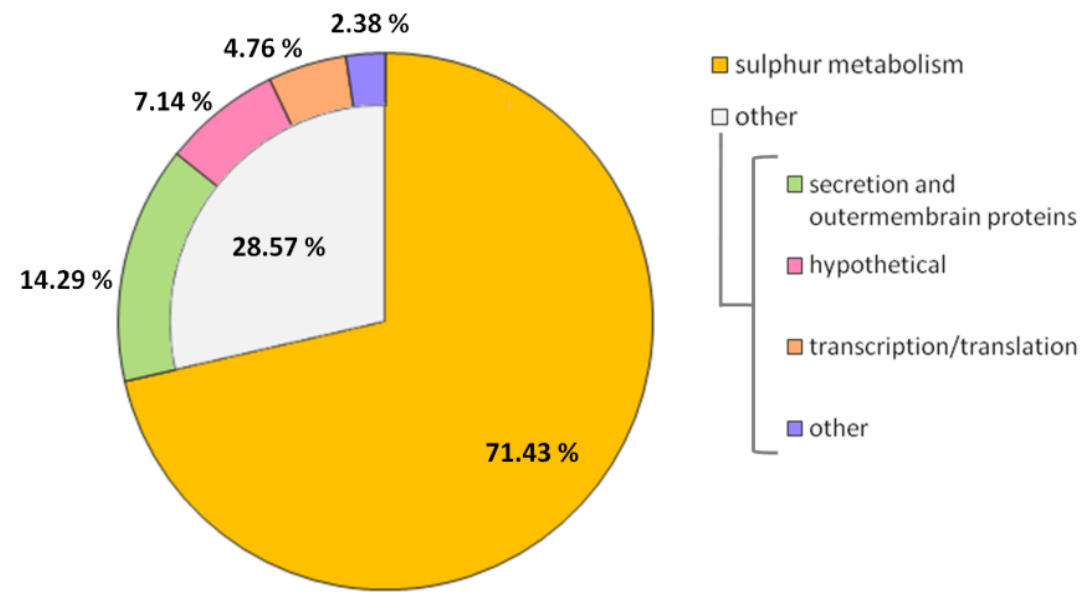

Figure 6. Classification of genes differentially expressed in the $\triangle P A 2504$ mutant compared to wildtype PAO1161. Triplicate samples of each strain were withdrawn from the stationary phase. A total of 42 genes were classified, 30 of them as involved in sulphur metabolism based on the Pseudomonas Genome database or Blast ${ }^{\circledR}$ homology.

Downregulated transcripts connected to sulphate and thiosulphate import included cys $A$, cys $W$, cysT, sbp, cysP, and PA2329; those connected with the transport of aliphatic 
sulphonic acids were $P A 2594$ and $P A 5103$ and with the import of cysteine and methionine PA2202, PA2203, PA2204, PA3931, and PA4195. The second group related to the conversion of sulphate to sulphite and further to sulphide: $c y s D, c y s N$, cysH, and cysI. Furthermore, transcripts coding for enzymes participating in the transformation of L-homocysteine to L-cysteine (review [15]), cystathionine beta-synthase (PA0399), and cystathionine gammalyase (PA0400) were downregulated in the $\triangle P A 2504$ mutant, as was PA2562, a homolog of the $E$. coli iscS gene coding for L-cysteine desulphurase [16] (Table 2).

\subsection{Growth of $\triangle P A 2504, \triangle r p p H$, and $\triangle P A 2504 \Delta r p p H$ Mutants on Different Sulphur Sources}

The transcriptomic analysis suggested that PA2504 could be involved in sulphur transport and metabolism. Therefore, we compared the growth of the $\triangle P A 2504$ and PAO1161 parental strains on M9 minimal medium supplemented with different sulphur source such as sulphate, thiosulphate, or amino acids cysteine and methionine. Surprisingly, no major differences were seen between the two strains in the exponential or stationary phase of growth regardless of the sulphur source (Figure 7).

To confirm these results, the Biolog system, which allows a simultaneous measurement of bacterial growth on many different sulphur sources, was used. Again, no significant differences in growth between the mutant and the parental strain were observed (Figure S6, Supplementary Materials).

Since PA2504 is the partner of RppH, whose involvement in sulphur metabolism was noticed [17], we asked whether the absence of RppH could affect growth on various sulphur sources in the presence or absence of PA2504. The growth curves of $\triangle P A 2504, \triangle r p p H$, and the double mutant $\triangle P A 2504 \triangle r p p H$ on different sulphur sources were determined. Notably, the $\triangle r p p H$ strain showed slower growth on cysteine, methionine, taurine, and MOPS than $\triangle P A 2504$ and the parental strain, but this effect was not influenced by the absence of PA2504 (strain $\triangle P A 2504 \triangle r p p H$ ) (Figure S7, Supplementary Materials).

Taken together, these results show that despite affecting the expression of numerous sulphur related genes, PA2504 is not involved in the transport or metabolism of any of the tested sulphur compounds.
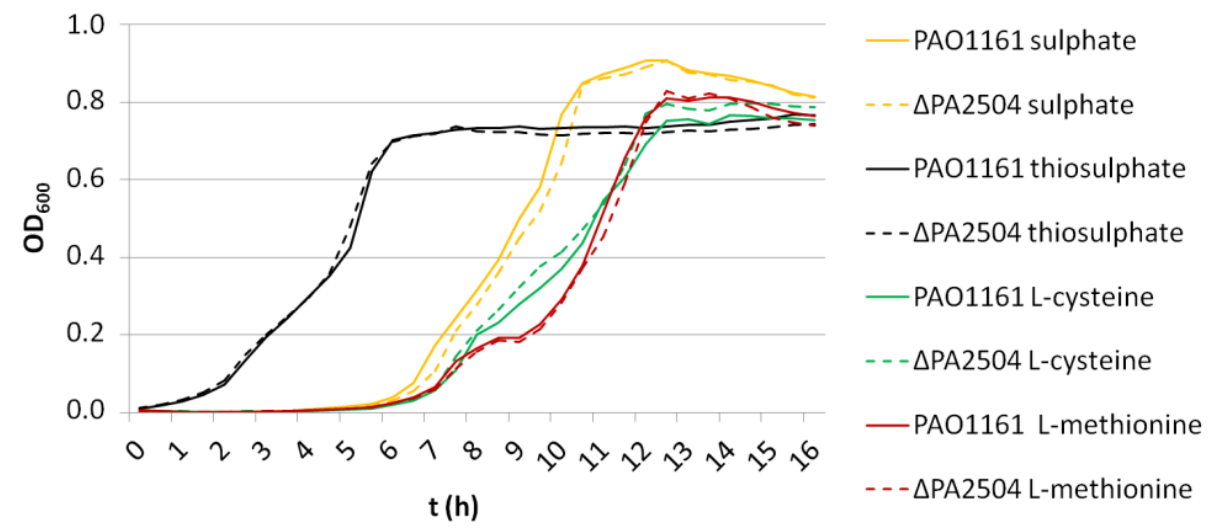

Figure 7. Growth of $P$. aeruginosa strains on $\triangle P A 2504$ mutant in modified M9 minimal medium supplemented with different sulphur sources $(0.5 \mathrm{mM})$.

\subsection{Search for PA2504 Cellular Partners}

To further search for PA2504 function, we attempted to identify its protein partners other than RppH. To this end, His-tagged PA2504 was expressed in P. aeruginosa grown to exponential or stationary phase, in vivo protein crosslinking was performed, and PA2504 proteins were separated by electrophoresis following crosslink reversal as described in the Materials and Methods.

Interestingly, following crosslink, two protein bands appeared specifically in the stationary phase of culture growth (Figure 8). 


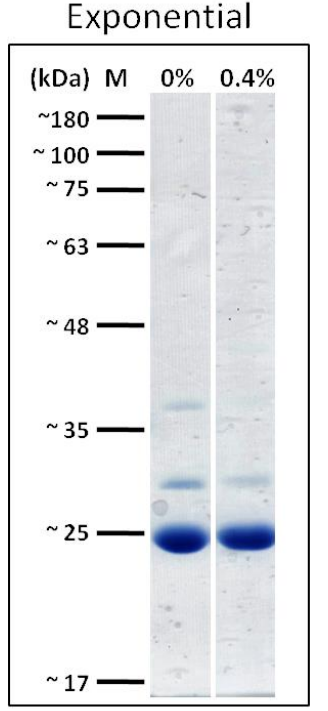

(a)

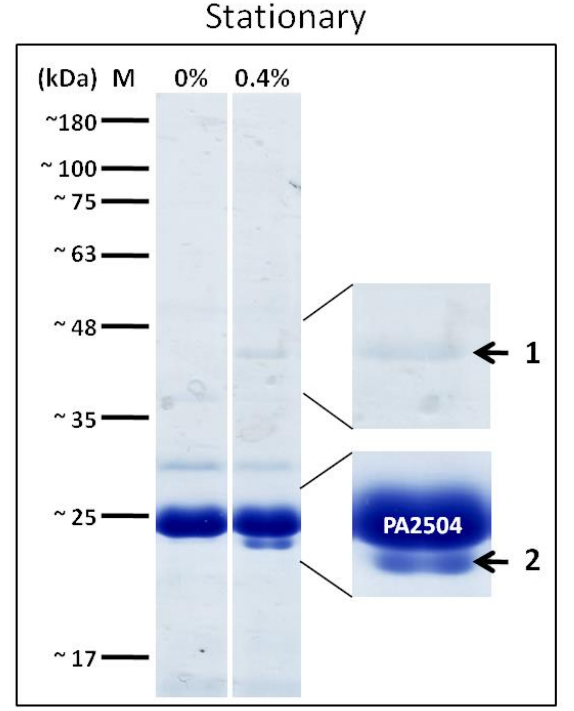

(b)

Figure 8. Search for PA2504 partners. Expression of PA2504 was induced with $0.2 \%$ arabinose in P. aeruginosa $\triangle P A 2504$ carrying pKGB2504. The potential PA2504 complexes were crosslinked with $0.4 \%$ formaldehyde for $10 \mathrm{~min}$, and purified as described in the Materials and Methods. Crosslinks were reversed by heating at $100{ }^{\circ} \mathrm{C}$ for $10 \mathrm{~min}$ and the proteins were separated by SDS-PAGE. (a) Proteins interacting with PA2504 in the exponential phase. (b) Proteins interacting with PA2504 in the stationary phase. In the enlarged fragments, arrows indicate additional bands specific to stationary phase located between $35 \mathrm{kDa}$ and $45 \mathrm{kDa}$ and below $25 \mathrm{kDa}$. Uncropped photos of the gels are presented in Supplementary Figure S8.

A mass spectrometry analysis of the first band identified, with high confidence, based on the mascot score and emPAI values, the $43.4 \mathrm{kDaTufA}$ translation elongation factor (PA4265), while in the second band, the presence of the $23.3 \mathrm{kDa}$ S4 ribosomal protein (PA4239) and the $23.6 \mathrm{kDa}$ GacA transcription regulator were detected. The results of mass spectrometry analysis are presented in Table S3 in the Supplementary Materials.

Interestingly, $\mathrm{RppH}$ was not observed under the experimental conditions used, suggesting that if the interaction between $\mathrm{RppH}$ and PA2504 occurs in P. aeruginosa cells, it happens under different circumstances.

\section{Discussion}

A variety of techniques were used to search for the biological function of PA2504 protein, the alleged only partner of the RppH hydrolase from P. aeruginosa. A lack or overproduction of PA2504 did not affect bacterial growth in various experimental conditions, nor was there an influence of PA2504 on biofilm formation, motility, or antibiotic resistance. In contrast to $\mathrm{RppH}$, whose absence dysregulates pyocyanin production [5], a lack of PA2504 did not affect it, suggesting that pyocyanin synthesis does not require the presence of the putative PA2504/RppH protein complex. Additionally, PA2504 did not associate with any particular cellular structure that could point into its function.

In addition, despite the results of a transcriptomic analysis strongly suggesting an indirect involvement of PA2504 in sulphur metabolism, its absence alone or in combination with RppH did not affect bacterial growth on a large array of sulphur compounds. However, taking into consideration the substantial number of sulphur derivatives found in nature and the enormous environmental adaptability of $P$. aeruginosa, one cannot exclude that PA2504 does in fact participate in a yet unrecognised sulphur pathway. In this context, our finding that the absence of $\mathrm{RppH}$ hampered growth on some of the sulphur sources tested seems interesting and worthy of further studies.

Having found virtually no physiological consequences of PA2504 absence, we were nevertheless able to gain some insight into its possible role by identifying its in vivo protein 
partners. Notably, these interactions appeared to be specific to the stationary phase of growth, when PA2504 is known to be upregulated. The partners included the elongation factor TufA (EF-TuA), the ribosomal protein S4, and the global response regulator GacA.

$\mathrm{S} 4$ ribosomal protein is essential for $30 \mathrm{~S}$ ribosome assembly (for review see [18]). Mutation of the gene encoding this protein increases the level of translation errors [19]. Apart from its role in ribosome biogenesis, $\mathrm{S} 4$ may function as a general anti-termination factor in transcription [20].

Similarly to S4, the elongation factor EF-Tu, whose canonical role is to transport aminoacylated tRNA to the ribosome [21], has evolved the ability to perform other functions. Its involvement in cell adhesion and biofilm formation, pathogenesis, and stringent response has beenreported [22-24] and possibly the list of diversities is not close yet.

GacA is a component of the global signal transduction system GacS/GacA highly conserved in Gram-negative bacteria. This regulatory system is required for the production of many secondary metabolites and extracellular enzymes including virulence factors and biocontrol factors linked with the adaptability to the environment [25]. In addition, a transcriptomic analysis of a P. aeruginosa gacA mutant also showed that transcripts coding for proteins of primary metabolism including those involved in sulphur metabolism were affected [26].

Interestingly, as shown by molecular modelling, PA2504 contains a Tudor-like domain. Tudor domain proteins, identified and extensively studied in eukaryotes, function as molecular adaptors, binding methylated arginine or lysine residues on their substrates to promote physical interactions and assembly of macromolecular complexes participating in diverse cellular pathways mostly connected with nucleic acid metabolism. Moreover, it was observed that the specificity of some Tudor domain proteins depend on their ability to form homodimers (review, [12,27]). Although similar complexes are yet to be found in prokaryotic cells, Tudor-like domains have been identified in several bacterial species [28-31]. There is also increasing evidence for protein arginine methylation in prokaryotes. Recently, a proteomic analysis found methylated arginine in the outer membrane protein TamA of E. coli [32] and Mycobacterium tuberculosis methylation at lysine and/or arginine residues was identified in nine proteins including MtrA, an essential response regulator of a twocomponent signalling system. The methylation of MtrA attenuated its binding to DNA [33]. In addition, it was shown that trimethylation of lysine 5 of EF-Tu was important for initial adhesion of P. aeruginosa cells to host epithelium [34]. Moreover, it was noticed that this modification had no impact on the primary function of EF-Tu [35], suggesting that depending on posttranslational modifications, the protein may play a different role.

Although, the Tudor-like domain of PA2504 seems to retain an aromatic cage, probably for accepting modified amino acids of other proteins, its more detailed biological function remains elusive. Proteins interacting with histones present extensive positively charged patches on their surfaces $[10,11]$ and those specialised in binding to one well-defined protein display unique electrostaticpatterns [12-14]. It appears that PA2504 is negatively charged at its surface, which suggests that it will rather not interact with proteins immediately attached to nucleic acids. On the other hand, it might hijack positively charged nucleic acids-binding proteins and block their native functions.

Further studies are needed to explain in detail how homodimeric PA2504 influences the biological function of S4, EF-TuA, and GacA, but it could be speculated that it might be required to bind these factors in order to fine tune cellular response to external conditions (e.g., stationary phase-dependent nutrient shortage).

\section{Materials and Methods}

\subsection{Bacterial Strains and Growth Conditions}

The E. coli and P. aeruginosa strains used in this study are listed in Table S1 in the Supplementary Materials and the plasmids in Table 3. Bacteria were grown routinely in Luria-Bertani (L-broth) medium or on L-agar (L-broth with $1.5 \%$ (wt/vol) agar) at $37^{\circ} \mathrm{C}$. To determine growth on different sulphur sources, P. aeruginosa strains were grown in 
modified M9 minimal medium (33.7 mM Na $2 \mathrm{HPO}_{4}, 22 \mathrm{mM} \mathrm{KH}_{2} \mathrm{PO}_{4}, 8.55 \mathrm{mM} \mathrm{NaCl}, 9.35$ $\mathrm{mM} \mathrm{NH}_{4} \mathrm{Cl}, 1.0 \mathrm{mM} \mathrm{MgCl}_{2}, 0.3 \mathrm{mM} \mathrm{CaCl}_{2}, 152 \mathrm{mM}$ leucine, $134 \mu \mathrm{M} \mathrm{FeCl}_{3}, 20 \mathrm{mM}$ sodium citrate), and supplemented with appropriate sulphur sources $(0.5 \mathrm{mM})$. Growth curves were obtained with the use of a Varioscan Lux multimode plate reader (Thermo Scientific ${ }^{\mathrm{TM}}$ ) in 96-well plates.

Where needed, appropriate antibiotics were added to the media as follows: ampicillin, $100 \mu \mathrm{g} \mathrm{mL}^{-1}$ for $\mathrm{Ap}^{\mathrm{R}}$ in E. coli, kanamycin sulphate, $50 \mu \mathrm{g} \mathrm{mL}^{-1}$ for $\mathrm{Km}^{\mathrm{R}}$ in E. coli, $25 \mu \mathrm{g} \mathrm{mL}{ }^{-1}$ chloramphenicol for $\mathrm{Cm}^{\mathrm{R}}$ in E. coli, and $200 \mu \mathrm{g} \mathrm{mL}^{-1}$ in P. aeruginosa; carbenicillin disodium salt, $300 \mu \mathrm{g} \mathrm{mL}{ }^{-1}$ for $\mathrm{Cb}^{\mathrm{R}}$ in $P$. aeruginosa; rifampicin, $300 \mu \mathrm{g} \mathrm{mL}^{-1}$ for Rif $\mathrm{R}$ in $P$. aeruginosa.

Table 3. Plasmids used in this study.

\begin{tabular}{|c|c|c|}
\hline Plasmid & Relevant Features & Source \\
\hline pKGB & $\begin{array}{l}\text { pKGB8.0.2 vector, in this work referred to as } \mathrm{pKGB} \text {; } \operatorname{araBADp}, \operatorname{araC}, \mathrm{Cm}^{\mathrm{R}} \text {, } \\
\text { broad-host-range expression vector }\end{array}$ & [36] \\
\hline pQE-80L & ${ }^{o r i} i_{C o l E 1}$ ApR T5p lacOlacIq His6 tag, expression vector & Qiagen \\
\hline pAKE600 & ori $_{M B 1}$ ori $_{R K 2} \mathrm{Ap}^{\mathrm{R}_{S a c B}}$ & [37] \\
\hline pKT25 & ori $P_{15 A}, \mathrm{Km}^{\mathrm{R}}$, lacp-cyaT25 & {$[38]$} \\
\hline pKNT25 & orip15, $\mathrm{Km}^{R}$, lacp-cyaT25 & [38] \\
\hline pUT18C & ori $_{\text {ColE1 }}, \mathrm{Ap}^{\mathrm{R}}$, lacp-cyaT18 & {$[38]$} \\
\hline pBAD24-sfGFPx1 & $\begin{array}{c}\operatorname{araBADp}, \operatorname{araC}, \mathrm{Ap}^{\mathrm{R}}, \begin{array}{l}\text { Superfolder GFP ORF cloned into pBAD24 for } \\
\text { expression in } E . \text { coli }\end{array} \\
\end{array}$ & [39] \\
\hline pAKE2504 & $\begin{array}{l}\text { pAKE600 plasmid with } 275 \text { bp upstream region of PA2504 gene with start } \\
\text { codon and } 253 \text { bp downstream region of PA2504 gene with stop codon, } \\
\text { inserted as EcoI-PstI and PstI-BamHI fragments }\end{array}$ & This work \\
\hline pQE2504 & pQE-80L with PA2504 without start codon, inserted as BamHI-SalI fragment & This work \\
\hline pKGB2504 & pKGB with PA2504Hisx6 inserted as EcoRI-SalI fragment & This work \\
\hline pKGBgfp2504 & $\begin{array}{l}\text { pKGB with sfGFP without stop codon, inserted as an EcoRI-HindIII fragment, } \\
\text { and PA2504 without start codon, cloned as XbaI-SacI fragment }\end{array}$ & This work \\
\hline pKT2504 & pKT25 with PA2504 without start codon, inserted as BamHI-EcoRI fragment & This work \\
\hline pNTrppH & pKNT25 with PA2504 without stop codon, inserted as BamHI-EcoRI fragment & This work \\
\hline p18C2504 & pUT18C with PA2504 without start codon, inserted as BamHI-EcoRI fragment & This work \\
\hline
\end{tabular}

\subsection{Deletion of PA2504}

$\triangle P A 2504$ and $\triangle P A 2504 \Delta r p p H$ mutants were obtained as follows: PA2504 upstream and downstream DNA fragments of about 300-500 nucleotides each were amplified by PCR using chromosomal DNA as a template and subsequently ligated into the suicide pAKE600 vector. pAKE600 carries the pMBIori, allowing replication in P. aeruginosa [37]. E. coli S17-1 was transformed with the obtained pAKE2504 plasmid and the transformants were conjugated with $P$. aeruginosa PAO1161 (for $\triangle P A 2504$ ) or $\Delta r p p H$ (for $\triangle P A 2504 \Delta r p p H$ ) using the procedure described by [40]. Following removal of the integrated suicide vector, P. aeruginosa colonies were analysed by RT-PCR to determine whether the allele exchange was successful, and the transcript of the gene was absent (Figure S1, Supplementary Materials).

\subsection{Overproduction of PA2504}

The PA2504 gene without the start codon was cloned into the pQE-80L vector to obtain a $\mathrm{His}_{6}$ PA2504 fusion. The $\mathrm{His}_{6}$ PA2504 fragment was cloned into the pKGB vector under the control of an arabinose inducible promoter to obtain the pKGB2504 plasmid. The obtained plasmid was introduced into suitable P. aeruginosa strains by conjugation as stated above. For protein overproduction, overnight cultures of $P$. aeruginosa carrying the plasmid 
were diluted in L-broth or M9 medium 1:100 and protein production was induced by the addition of $0.02 \%$ arabinose.

\subsection{Pyocyanin Quantification}

Overnight cultures of P. aeruginosa PAO1161 and mutant strains were inoculated 1:100 in $20 \mathrm{~mL}$ of L-broth and grown in triplicate at $37^{\circ} \mathrm{C}$ with aeration. After $12 \mathrm{~h}$ of incubation, two $7.5 \mathrm{~mL}$ samples were withdrawn from each culture and extracted with $4.5 \mathrm{~mL}$ of chloroform and then $1.5 \mathrm{~mL} 0.2 \mathrm{M} \mathrm{HCl}$ was added to the extract, causing the colour change. $\mathrm{OD}_{520}$ was determined and the obtained values were converted to pyocyanin content following [41]. The experiment was repeated at least three times.

\subsection{Molecular Protein Modelling}

Sequence similarity searches were performed using hhsearch, a highly sensitive meta profile comparison engine for remote homology detection [42]. Additionally, the full-length PA2504 protein was modelled with TrRosetta [43], which combines energy minimisation with restraints estimated by the neural network. Multiple sequence alignments were obtained with Mafftlinsi flavour [44] for accuracy. Secondary structure was predicted using PSIPRED [45]. Proteins similar in structure to the PA2504 model were identified using the DALI server [46]. Electrostatic analysis was done with the APBS [47] plugin to PyMOL. All 3D structure visualisations were prepared in PyMOL.

\subsection{Purification of His ${ }_{6}$-Tagged PA2504 by Affinity Chromatography}

The pQE2504 plasmid carrying the PA2504 gene coding a protein in fusion with a $\mathrm{His}_{6}$-tag was introduced into E. coli BL21-DE3. An overnight culture of E. coli transformant was diluted 1:50 in $100 \mathrm{~mL}$ of L-broth and grown at $37^{\circ} \mathrm{C}$ to $\mathrm{OD}_{600}=0.6$. Then, IPTG was added to $0.2 \mathrm{mM}$, cells were grown for the next $3-4 \mathrm{~h}$, and pelleted by centrifugation for $10 \mathrm{~min}$ at $4{ }^{\circ} \mathrm{C}$. The pellets were suspended in $8 \mathrm{~mL}$ of sonication buffer $(300 \mathrm{mM} \mathrm{NaCl}$, $100 \mathrm{mM}$ Tris-Cl, $\mathrm{pH} 7.5,5 \mathrm{mM} \beta$-mercaptoethanol) containing protease inhibitors (Roche, Basel, Switzerland or Sigma Aldrich Saint Louis, MO, USA) and disrupted by sonication $(5 \times 1 \mathrm{~min})$. The obtained cell extract was cleared by centrifugation at $4{ }^{\circ} \mathrm{C}$ for $30 \mathrm{~min}$ at $14,000 \mathrm{~g}$. The supernatant was incubated with $200 \mu \mathrm{L}$ of $\mathrm{Ni}^{2+}$-NTA resin (Sigma Aldrich, Saint Louis, MO, USA) for $2 \mathrm{~h}$ with gentle shaking at $4{ }^{\circ} \mathrm{C}$. The resin was washed twice with sonication buffer, then three times with sonication buffer containing $10 \mathrm{mM}$ imidazole (Sigma Aldrich, Saint Louis, MO, USA), and three times with sonication buffer containing $20 \mathrm{mM}$ imidazole. Resin-bound proteins were then eluted with three $200 \mu \mathrm{L}$ portions of $250 \mathrm{mM}$ imidazole and dialysed overnight against dialysis buffer (50 mM Tris-Cl, $\mathrm{pH} 7.0$, $2 \mathrm{mM}$ EDTA, $2 \mathrm{mM}$ DTT). Protein purity was analysed by SDS-PAGE and concentration measured using the Bradford reagent [48].

\subsection{SEC-MALS Analysis}

The purified recombinant PA2504 protein was loaded onto a Superdex200 column combined with a multi-angle light scattering instrument HELEOS (WYATT Technology, Santa Barbara, CA, USA). The proteins were eluted with $50 \mathrm{mM}$ Tris-Cl buffer, $\mathrm{pH}$ 7.0, $300 \mathrm{mM} \mathrm{NaCl}$, at a flow rate of $0.5 \mathrm{~mL} \mathrm{~min}^{-1}$. Each fraction was automatically analysed by multi-angle light scattering.

\subsection{Bacterial Two-Hybrid System (BACTH)}

DNA fragments encoding PA2504 and RppH were PCR-amplified using P. aeruginosa genomic DNA as template with appropriate primers (Table S2). The obtained fragments were cloned into the plasmids of the BACTH system [38]. Resulting plasmids pKT2504, $\mathrm{pNTrppH}$, and $\mathrm{p} 18 \mathrm{C} 2504$ were co-transformed into the E. coli BTH101 cyaA strain as needed. The transformants were analysed on MacConkey selective medium plates with maltose. As negative controls, the BTH101 strain transformed with one empty vector and one encoding the hybrid protein was used. 


\subsection{Bacterial Two-Hybrid Library Screening}

A library of the P. aeruginosa PAO1161 genome in the pUT18C plasmid was used [9]. Briefly, DNA from P. aeruginosa PAO1161 was fragmented with helium at $0.9 \mathrm{~Pa}$ for $4 \mathrm{~min}$, precipitated, dried, and dissolved in water. The DNA fragments were treated with Klenow DNA polymerase I and T4 phage polymerase and then ligated into the SmaI-treated and dephosphorilated pUT18C BACTH vector. The obtained plasmids were introduced into the E. coli cells. The bacteria were collected to obtain a 10-fold coverage of the whole P. aeruginosa PAO1161 genome and inoculated into LB medium for library isolation. Three milligrams of plasmid DNA library was used for further experiments.

The pNTrppH plasmid and the pUT18C library were co-transformed into the E. coli BTH101 cyaA strain. A four-step verification was used. First, the transformed cells were spread on LB plates with $0.5 \mathrm{mM}$ IPTG and $40 \mu \mathrm{g} \mathrm{mL}{ }^{-1}$ X-Gal. The plates were incubated for five days at $28^{\circ} \mathrm{C}$. Blue colonies were replicated on MacConkey selection medium and incubated $48 \mathrm{~h}$ in $28^{\circ} \mathrm{C}$. Plasmids where isolated from streaks thatchanged in colour to red. The obtained plasmids were co-transformed with pNTrppH into E. coli BTH101 cyaA and the bacteria were spread on LB X-Gal IPTG plates. Library plasmids from blue colonies were sequenced in house and the sequences were verified for protein-coding correct frame orientation. When the above conditions were met, the protein encoded by the fragment was considered as a potential partner of $\mathrm{RppH}$. To confirm the interactions, the entire genes encoding the identified proteins were cloned in PUT18C and then co-transformed with pNTrppH into the E. coli BTH101 cyaA and selected LB X-Gal IPTG medium. In each step of the procedure a positive and a negative control was used.

For the identification of the protein partners of $\mathrm{RppH}, 21$ co-transformations of the pNTrppH with the pUT18C library were performed. Of the approximately 35,000 colonies analysed, 24 showed a change incolour. After MacConkey medium selection, eight clones were selected for further analysis. Upon re-analysis, only two clones showed a change incolour on the selection medium and upon sequence analysis, only one carrying the PA2504 gene encoding an unknown protein was accepted. The interaction of PA2504 with $\mathrm{RppH}$ was confirmed as detailed above.

\subsection{Cellular Localisation of PA2504}

PA2540 protein was localised in P. aeruginosa cells by cloning the PA2504 and sfGFP (super folder GFP) fragments in to the pKGB to give pKGBgfp2504. PA2504 was amplified on the PAO1161 strain genomic DNA template and $s f G F P$ fragment on the pBAD24sfGFPx1 plasmid [39]; pKGBgfp2504 was introduced into the P. aeruginosa $\triangle P A 2504$ by conjugation [40]. An overnight culture was diluted $1: 150$ and incubated for $4 \mathrm{~h}$ at $37^{\circ} \mathrm{C}$, then $1.5 \mathrm{~mL}$ of the culture was centrifuged and resuspended in $20 \mu \mathrm{L}$ of fresh LB medium and $1 \mu \mathrm{L}$ of the suspension was placed on a microscope slide covered with polylysine (Thermo Scientific). Cells were studied using a Zeiss Imager. M2 fluorescence microscope with a $100 \times 1.30$ NA Plan-Neofluar lens and Zeiss AxioCam MRc5 camera with ta 470/40 nm excitation filter, $495 \mathrm{~nm}$ dichroic beam-splitter, and 525/50 nm emission filter. AxioVision (AxioVs40 V 4.8.2.0, Carl Zeiss MicroImaging) software was used.

\subsection{In Vivo Protein Crosslinking and Purification of Protein Complexes}

Crosslinking experiments were based on [49]. The minimal concentration of formaldehyde and incubation time required to induce sufficient crosslinking were determined experimentally. P. aeruginosa $\triangle P A 2504$ strain carrying the pKGB2504 plasmid, encoding His $_{6}$-taged PA2504, was used. An overnight culture was diluted 1:100 in fresh L-broth medium with $0.2 \%$ arabinose and chloramphenicol and grown for $18 \mathrm{~h}$ at $37^{\circ} \mathrm{C}$ with vigorous shaking. Formaldehyde was added to cultures in a range of concentrations from $0.1 \%$ to $1 \%$ and the bacteria were incubated for $15 \mathrm{~min}$ at room temperature with gentle shaking every $3 \mathrm{~min}$. The formaldehyde was quenched by the addition of 1/10 culture volume of ice cold $0.125 \mathrm{M}$ glycine in PBS and $100 \mathrm{~mL}$ of each culture was centrifuged in $5000 \mathrm{rpm}$ for $30 \mathrm{~min}$, washed with $50 \mathrm{~mL}$ of cold PBS, and centrifuged again. The pellets 
were suspended in $8 \mathrm{~mL}$ of sonication buffer $(300 \mathrm{mM} \mathrm{NaCl}, 100 \mathrm{mM}$ Tris-Cl, $\mathrm{pH} 7.5$, $5 \mathrm{mM} \beta$-mercaptoethanol) containing protease inhibitors (Sigma Aldrich, Saint Louis, MO, USA) and disrupted by sonication $(5 \times 1 \mathrm{~min})$. The obtained cell extracts were cleared by centrifugation at $4{ }^{\circ} \mathrm{C}$ for $30 \mathrm{~min}$ at $14,000 \mathrm{~g}$. Supernatants were incubated with $200 \mu \mathrm{L}$ of $\mathrm{Ni}^{2+}$-NTA resin (Sigma Aldrich, Saint Louis, MO, USA) for $2 \mathrm{~h}$ with gentle shaking at $4{ }^{\circ} \mathrm{C}$. The resin was washed twice with sonication buffer and then three times with sonication buffer containing $10 \mathrm{mM}$ imidazole (Sigma Aldrich, Saint Louis, MO, USA) and three times with sonication buffer containing $20 \mathrm{mM}$ imidazole. His 6 -tagged PA2504 crosslinked with its protein partners was eluted from the nickel resin with three portions of $200 \mu \mathrm{L}$ of $400 \mathrm{mM}$ imidazole (then pooled). The proteins were incubated with loading dye at $65{ }^{\circ} \mathrm{C}$ for $20 \mathrm{~min}$, which preserves the crosslinking [50]. The crosslinked proteins were separated on SDS-PAGE gel followed by western blotting. Aconcentration of $0.4 \%$ formaldehyde and $10 \mathrm{~min}$ incubation were chosen for further experiments based on the visibility of the PA2504 dimer and larger complexes. For mass spectrometry identification of the crosslinked proteins, the Ni-NTA-isolated complexes were incubated with the loading dye for $10 \mathrm{~min}$ at $100{ }^{\circ} \mathrm{C}$, which disrupted the formaldehyde crosslinks. Proteins from three separate biological replicates treated with $0.4 \%$ formaldehyde and three not treated with formaldehyde were separated in 12\% SDS-PAGE gel.

\subsection{Mass Spectrometry}

The bands of interest were cut out from the gel and fragmented to 1-2 mm pieces with sterilised scalpel. For Coomassie Brilliant blue removal, gel fragments were covered with destaining solution (50\% acetonitrile in $\left.50 \mathrm{mM} \mathrm{NH} \mathrm{HCO}_{3}\right)$ and vortexed until fully destained. The gel fragments were dried with $100 \%$ acetonitrile, followed by cysteine reduction with a solution of $10 \mathrm{mM} \mathrm{DTT,} 100 \mathrm{mM} \mathrm{NH}_{4} \mathrm{HCO}_{3}$ for $30 \mathrm{~min}$ in $57{ }^{\circ} \mathrm{C}$. The gel was dried again as previously described and cysteine alkylation was performed by 45 min of incubation in alkylation solution (50 mM iodoacetamid, $100 \mathrm{mM} \mathrm{NH}_{4} \mathrm{HCO}_{3}$ ). Any residue of used solutions were washed away with $100 \mathrm{mM} \mathrm{NH}_{4} \mathrm{HCO}_{3}$ and subsequently with $100 \%$ acetonitrile, used twice, alternately. The gel was dried again as previously described. The dry gel fragments were covered with a trypsin solution $(10 \mathrm{ng} / \mu \mathrm{L}$ in $25 \mathrm{mM}$ $\mathrm{NH}_{4} \mathrm{HCO}_{3}$ ) and incubated at $37^{\circ} \mathrm{C}$ overnight. The obtained peptides were extracted with $30 \mu \mathrm{L}$ of $0.1 \%$ trifluoroacetic acid, and $0.2 \%$ acetonitrile solution. The peptide mixture was separated with liquid chromatography, followed by mass measurements with an Orbitrap spectrometer (Thermo). The peptides were annotated to the P. aeruginosa proteome with the use of the Pseudomonas genome data base [3] with the use of MASCOT (http: / / www.matrixscience.com (accessed on 22 April 2021 and 9 August 2021)).

\subsection{RNA Isolation}

For isolation of total cellular RNA for next-generation sequencing (RNA-Seq) or RTqPCR, P. aeruginosa PAO1161 and $\triangle P A 2504$ strains were inoculated 1:100 in fresh L-broth and incubated for $18 \mathrm{~h}$ with shaking at $37^{\circ} \mathrm{C}$, then $1.5 \mathrm{~mL}$ samples were taken from three independent biological replicates and immediately treated with RNA protect Bacteria Reagent (Qiagen, Hilden, Germany) and spun down. RNA was isolated from the cell pellet with the RNeasy Mini Kit (Qiagen) and digested with DNase I using the RapidOut DNA Removal Kit (Thermo Scientific, Waltham, MA, USA). RNA quality and integrity was assessed with a bioanalyzer (Agilent Technology, Santa Clara, CA, USA), and concentration was estimated using a Nano Drop ND-1000 spectrophotometer.

\subsection{4. $R T-q P C R$}

Total RNA (800 ng) from three biological replicates of each strain was used for cDNA synthesis using a QuantiTect Reverse Transcription Kit (Qiagen). The cDNA then served as a template for qPCR with gene-specific primers (Table S2, Supplementary Materials) and $5 \times$ HOT FIREPolEvaGreen qPCR Mix Plus (Solis Biodyne) in a LightCycler 480 II System (Roche Molecular Diagnostics). Relative transcript level was determined by a comparisonof 
crossing points $(\mathrm{Cp})$ for the target and the reference gene (nadB). Three technical repetitions were undertakenfor each primer pair. The ratio/fold change was calculated using Pfaffl's formula [51].

\subsection{RNA-Seq Analysis}

RNA as above prepared was subjected to next-generation sequencing by a commercial provider. Ribosomal RNA was depleted using QIAseqFastSelect (Qiagen). cDNA libraries were prepared with the NEBNext ${ }^{\circledR}$ Ultra $^{\text {TM }}$ II Directional RNA Library Prep Kit for Illumina ${ }^{\circledR}$ (New England Biolabs) with information about the transcription direction preserved and sequenced on a NextSeq500 device (Illumina) with 75-nt paired-end reads.

\subsection{Bioinformatic Analysis of RNA-Seq Results}

First, for each file with raw sequencing data, a data quality report was prepared with the use of FASTQC [52]. The reads were mapped with TopHat program [53] to the $P$. aeruginosa PAO1 genome using the fr-firststrand option and in the nonovel-juncs mode. The percentage of reference mapping reads was then verified. The number of mapped base pair reads for individual genes was counted with HTseq [54] with distinction considering the transcript strand (-stranded=reverse). Genes were annotated based on the P. aeruginosa PAO1 gene descriptions from PseudoCap. Final results were prepared in the R environment (https: / / www.r-project.org/ (accessed on 9 June 2020)) with the use of the DESeq2 package [55]. Differential expression was analysed statistically with the Walds test. Obtained $p$-values were FDR-adjusted using the Benjamini-Hochberg method [56]. The RNA-Seq results were deposited at NCBI's Gene Expression Omnibus [57] and are accessible via the GEO Series Accession Number GSE179150 at [58] (https:/ / www.ncbi. nlm.nih.gov/geo/query/acc.cgi?acc=GSE179150).

Supplementary Materials: The following are available online at https:/ / www.mdpi.com/article/10 $.3390 /$ ijms22189833/s1. All supplementary materials are provided in a single pdf file. The content is as follows: Supporting Materials and Methods; Table S1: Bacterial strains used in this study; Table S2: Primers used in this study; Table S3: Proteins identified by mass spectrometry analysis of bands cut from SDS-PAGE gel; Figure S1: Control of PA2504 gene deletion; Figure S2: Effect of PA2504 depravation and overproduction on growth, biofilm production, motility, and antibiotic susceptibility; Figure S3: Interaction between PA2504 and RppH; Figure S4; Figure S5: Molecular surfaces of PHF1, ZMYND8, and PA2504 coloured according to calculated electrostatic potential; Figure S6: Effect of PA2504 depravation and overproduction in the presence of different sulphur sources; Figure S7: Growth curves of the P. aeruginosa wild-type PAO1161 strain and $\triangle r p p H, \triangle P A 2504, \triangle P A 2504 \Delta r p p H$ mutantstrains in M9 minimal medium supplemented with a sulphur source; Figure S8: Uncropped pictures of SDS-PAGE gels used to prepare Figure 8.

Author Contributions: J.D.: conceptualisation; methodology; formal analysis; investigation; writingoriginal draft preparation; writing - review \& editing; visualisation; project administration; funding acquisition; K.S.: methodology; formal analysis; investigation; writing-original draft preparation; writing—review \& editing; visualisation; M.K.: methodology; investigation; E.K.: conceptualisation; writing—original draft preparation; writing—review \& editing; supervision; project administration. All authors have read and agreed to the published version of the manuscript.

Funding: The majority of the work presented in this paper was funded by a PRELUDIUM UMO2018/29/N/NZ6/01701 grant from the National Science Centre (Narodowe Centrum Nauki), Poland. The equipment used for mass spectrometry was sponsored in part by the Centre for Preclinical Research and Technology (CePT), a project co-sponsored by the European Regional Development Fund and Innovative Economy, The National Cohesion Strategy of Poland.

Data Availability Statement: The RNA-Seq results were deposited in NCBI's Gene Expression Omnibus and are accessible through GEO Series accession number GSE179150 (https:/ / www.ncbi. nlm.nih.gov / geo / query / acc.cgi?acc=GSE179150 (accessed on 1 July 2021)).

Acknowledgments: The Pseudomonas aeruginosa BACTH library was provided courtesy of Msc Magdalena Kusiak and Grazyna Jagura-Burdzy. 
Conflicts of Interest: The authors declare no conflict of interest.

$\begin{array}{ll}\text { Abbreviations } \\ \text { BACTH } & \text { Bacterial two hybrid } \\ \text { DTT } & \text { Ditiotreitol } \\ \text { EDTA } & \text { Ethylenediamine tetraacetic acid } \\ \text { FC } & \text { Fold change } \\ \text { IPTG } & \text { Isopropyl } 3 \text {-D-1-thiogalactopyranoside } \\ \text { RNA-Seq } & \text { High-throughput RNA sequencing } \\ \text { RT-PCR } & \text { Reverse transcription PCR } \\ \text { RT-qPCR } & \text { Reverse transcription quantitative PCR } \\ \text { SEC-MALS } & \text { Exclusion chromatography combined with multi angle light scattering } \\ \text { X-Gal } & \text { 5-Bromo-4-Chloro-3-Indolyl } \beta \text {-D-Galactopyranoside }\end{array}$

\section{References}

1. Spagnolo, A.M.; Sartini, M.; Cristina, M.L. Pseudomonas aeruginosa in the Healthcare Facility Setting. Rev. Med. Microbiol. 2021, 32, 169-175. [CrossRef]

2. Jimenez, P.N.; Koch, G.; Thompson, J.A.; Xavier, K.B.; Cool, R.H.; Quax, W.J. The Multiple Signaling Systems Regulating Virulence in Pseudomonas aeruginosa. Microbiol. Mol. Biol. Rev. 2012, 76, 46-65. [CrossRef]

3. Winsor, G.L.; Lam, D.K.W.; Fleming, L.; Lo, R.; Whiteside, M.D.; Yu, N.Y.; Hancock, R.E.W.; Brinkman, F.S.L. Pseudomonas Genome Database: Improved Comparative Analysis and Population Genomics Capability for Pseudomonas Genomes. Nucleic Acids Res. 2011, 39, D596-D600. [CrossRef] [PubMed]

4. Deana, A.; Celesnik, H.; Belasco, J.G. The Bacterial Enzyme RppH Triggers Messenger RNA Degradation by $5^{\prime}$ Pyrophosphate Removal. Nature 2008, 451, 355-358. [CrossRef] [PubMed]

5. Kujawa, M.; Lirski, M.; Ziecina, M.; Drabinska, J.; Modzelan, M.; Kraszewska, E. Nudix-Type RNA Pyrophosphohydrolase Provides Homeostasis of Virulence Factor Pyocyanin and Functions as a Global Regulator in Pseudomonas aeruginosa: Nudix RNA Hydrolase Regulates, P. Aeruginosa Virulence. Mol. Microbiol. 2017, 106, 381-394. [CrossRef]

6. Bielecki, P.; Komor, U.; Bielecka, A.; Müsken, M.; Puchałka, J.; Pletz, M.W.; Ballmann, M.; Martins dos Santos, V.A.; Weiss, S.; Häussler, S. Ex Vivo Transcriptional Profiling Reveals a Common Set of Genes Important for the Adaptation of Pseudomonas aeruginosa to Chronically Infected Host Sites: Ex Vivo Transcriptional Profiling. Environ. Microbiol. 2013, 15, 570-587. [CrossRef]

7. Juhas, M.; Wiehlmann, L.; Huber, B.; Jordan, D.; Lauber, J.; Salunkhe, P.; Limpert, A.S.; von Götz, F.; Steinmetz, I.; Eberl, L.; et al. Global Regulation of Quorum Sensing and Virulence by VqsR in Pseudomonas aeruginosa. Microbiology 2004, 150, 831-841. [CrossRef] [PubMed]

8. Raneri, M.; Pinatel, E.; Peano, C.; Rampioni, G.; Leoni, L.; Bianconi, I.; Jousson, O.; Dalmasio, C.; Ferrante, P.; Briani, F. Pseudomonas aeruginosa Mutants Defective in Glucose Uptake Have Pleiotropic Phenotype and Altered Virulence in Non-Mammal Infection Models. Sci. Rep. 2018, 8, 16912. [CrossRef]

9. Kusiak, M.B. Molecular and Structural Analysis of parB Gene of Pseudomonas aeruginosa. Ph.D. Thesis, Department of Microbial Biochemistry IBB PAS, Warsaw, Poland, 5 October 2010.

10. Savitsky, P.; Krojer, T.; Fujisawa, T.; Lambert, J.-P.; Picaud, S.; Wang, C.-Y.; Shanle, E.K.; Krajewski, K.; Friedrichsen, H.; Kanapin, A.; et al. Multivalent Histone and DNA Engagement by a PHD/BRD/PWWP Triple Reader Cassette Recruits ZMYND8 to K14ac-Rich Chromatin. Cell Rep. 2016, 17, 2724-2737. [CrossRef]

11. Li, H.; Liefke, R.; Jiang, J.; Kurland, J.V.; Tian, W.; Deng, P.; Zhang, W.; He, Q.; Patel, D.J.; Bulyk, M.L.; et al. Polycomb-like Proteins Link the PRC2 Complex to CpG Islands. Nature 2017, 549, 287-291. [CrossRef]

12. Cui, G.; Park, S.; Badeaux, A.I.; Kim, D.; Lee, J.; Thompson, J.R.; Yan, F.; Kaneko, S.; Yuan, Z.; Botuyan, M.V.; et al. PHF20 Is an Effector Protein of P53 Double Lysine Methylation That Stabilizes and Activates P53. Nat. Struct. Mol. Biol. 2012, 19, 916-924. [CrossRef]

13. Ramos, A.; Hollingworth, D.; Adinolfi, S.; Castets, M.; Kelly, G.; Frenkiel, T.A.; Bardoni, B.; Pastore, A. The Structure of the N-Terminal Domain of the Fragile X Mental Retardation Protein: A Platform for Protein-Protein Interaction. Structure 2006, 14, 21-31. [CrossRef]

14. Hu, Y.; Chen, Z.; Fu, Y.; He, Q.; Jiang, L.; Zheng, J.; Gao, Y.; Mei, P.; Chen, Z.; Ren, X. The Amino-Terminal Structure of Human Fragile X Mental Retardation Protein Obtained Using Precipitant-Immobilized Imprinted Polymers. Nat. Commun. 2015, 6, 6634. [CrossRef] [PubMed]

15. Vermeij, P.; Kertesz, M.A. Pathways of Assimilative Sulfur Metabolism in Pseudomonas Putida. J. Bacteriol. 1999, $181,5833-5837$. [CrossRef] [PubMed]

16. Flint, D.H. Escherichia Coli Contains a Protein That Is Homologous in Function and N-Terminal Sequence to the Protein Encoded by the NifS Gene of AzotobacterVinelandii and That Can Participate in the Synthesis of the Fe-S Cluster of Dihydroxy-Acid Dehydratase. J. Biol. Chem. 1996, 271, 16068-16074. [CrossRef] 
17. Morigasaki, S.; Umeyama, A.; Kawano, Y.; Aizawa, Y.; Ohtsu, I. Defect of RNA PyrophosphohydrolaseRppH Enhances Fermentative Production of L-Cysteine in Escherichia Coli. J. Gen. Appl. Microbiol. 2020, 66, 307-314. [CrossRef]

18. Culver, G.M. Assembly of the 30S Ribosomal Subunit. Biopolymers 2003, 68, 234-249. [CrossRef] [PubMed]

19. Dahlgren, A.; Rydén-Aulin, M. A Novel Mutation in Ribosomal Protein S4 Thataffects the Function of a Mutated RF1. Biochimie 2000, 82, 683-691. [CrossRef]

20. Torres, M. Ribosomal Protein S4 Is a Transcription Factor with Properties Remarkably Similar to NusA, a Protein Involved in Both Non-Ribosomal and Ribosomal RNA Antitermination. EMBO J. 2001, 20, 3811-3820. [CrossRef]

21. Sprinzl, M. Elongation Factor Tu: A Regulatory GTPase with an Integrated Effector. Trends Biochem. Sci. 1994, 19, 245-250. [CrossRef]

22. Harvey, K.L.; Jarocki, V.M.; Charles, I.G.; Djordjevic, S.P. The Diverse Functional Roles of Elongation Factor Tu (EF-Tu) in Microbial Pathogenesis. Front. Microbiol. 2019, 10, 2351. [CrossRef]

23. López-Ochoa, J.; Montes-García, J.F.; Vázquez, C.; Sánchez-Alonso, P.; Pérez-Márquez, V.M.; Blackall, P.J.; Vaca, S.; NegreteAbascal, E. Gallibacterium Elongation Factor-Tu Possesses Amyloid-like Protein Characteristics, Participates in Cell Adhesion, and Is Present in Biofilms. J. Microbiol. 2017, 55, 745-752. [CrossRef] [PubMed]

24. Vinogradova, D.S.; Zegarra, V.; Maksimova, E.; Nakamoto, J.A.; Kasatsky, P.; Paleskava, A.; Konevega, A.L.; Milón, P. How the Initiating Ribosome Copes with PpGpp to Translate MRNAs. PLoS Biol. 2020, 18, e3000593. [CrossRef] [PubMed]

25. Heeb, S.; Haas, D. Regulatory Roles of the GacS/GacA Two-Component System in Plant-Associated and Other Gram-Negative Bacteria. MPMI 2001, 14, 1351-1363. [CrossRef] [PubMed]

26. Wei, X.; Huang, X.; Tang, L.; Wu, D.; Xu, Y. Global Control of GacA in Secondary Metabolism, Primary Metabolism, Secretion Systems, and Motility in the Rhizobacterium Pseudomonas aeruginosa M18. J. Bacteriol. 2013, 195, 3387-3400. [CrossRef] [PubMed]

27. Pek, J.W.; Anand, A.; Kai, T. Tudor Domain Proteins in Development. Development 2012, 139, 2255-2266. [CrossRef]

28. Kaur, G.; Dutta, D.; Thakur, K.G. Crystal Structure of Mycobacterium Tuberculosis CarD, an Essential RNA Polymerase Binding Protein, reveals a Quasidomain-Swapped Dimeric Structural Architecture: Crystal Structure of M. Tuberculosis CarD. Proteins 2014, 82, 879-884. [CrossRef]

29. Ortiz, C.; Kureisaite-Ciziene, D.; Schmitz, F.; McLaughlin, S.H.; Vicente, M.; Löwe, J. Crystal Structure of the Z-Ring Associated Cell Division Protein ZapC from Escherichia Coli. FEBS Lett. 2015, 589, 3822-3828. [CrossRef]

30. Forcada-Nadal, A.; Palomino-Schätzlein, M.; Neira, J.L.; Pineda-Lucena, A.; Rubio, V. The PipX Protein, When Not Bound to Its Targets, Has Its Signaling C-Terminal Helix in a Flexed Conformation. Biochemistry 2017, 56, 3211-3224. [CrossRef]

31. Kawale, A.A.; Burmann, B.M. UvrD Helicase-RNA Polymerase Interactions Are Governed by UvrD's Carboxy-Terminal Tudor Domain. Commun. Biol. 2020, 3, 607. [CrossRef] [PubMed]

32. Zhang, M.; Xu, J.-Y.; Hu, H.; Ye, B.-C.; Tan, M. Systematic Proteomic Analysis of Protein Methylation in Prokaryotes and Eukaryotes Revealed Distinct Substrate Specificity. Proteomics 2018, 18, 1700300. [CrossRef]

33. Singhal, A.; Virmani, R.; Naz, S.; Arora, G.; Gaur, M.; Kundu, P.; Sajid, A.; Misra, R.; Dabla, A.; Kumar, S.; et al. Methylation of Two-Component Response Regulator MtrA in Mycobacteria Negatively Modulates Its DNA Binding and Transcriptional Activation. Biochem. J. 2020, 477, 4473-4489. [CrossRef]

34. Widjaja, M.; Harvey, K.L.; Hagemann, L.; Berry, I.J.; Jarocki, V.M.; Raymond, B.B.A.; Tacchi, J.L.; Gründel, A.; Steele, J.R.; Padula, M.P.; et al. Elongation Factor Tu Is a Multifunctional and Processed Moonlighting Protein. Sci. Rep. 2017, 7, 11227. [CrossRef]

35. Prezioso, S.M.; Duong, D.M.; Kuiper, E.G.; Deng, Q.; Albertí, S.; Conn, G.L.; Goldberg, J.B. Trimethylation of Elongation Factor-Tu by the Dual Thermoregulated Methyltransferase EftM Does Not Impact Its Canonical Function in Translation. Sci. Rep. 2019, 9, 3553. [CrossRef] [PubMed]

36. Głabski, K.T. Role of Putative Partners of Par Proteins in Chromosome Segregation, Cell Division and Motility of Pseudomonas aeruginosa. Ph.D. Thesis, Department of Microbial Biochemistry IBB PAS, Warsaw, Poland, 6 June 2014.

37. El-Sayed, A.K.; Hothersall, J.; Thomas, C.M. Quorum-Sensing-Dependent Regulation of Biosynthesis of the Polyketide Antibiotic Mupirocin in Pseudomonas Fluorescens NCIMB 10586 The GenBank Accession Numbers for the Sequences Determined in This Work Are AF318063 (MupA), AF318064 (MupR) and AF318065 (MupI). Microbiology 2001, 147, 2127-2139. [CrossRef] [PubMed]

38. Karimova, G.; Pidoux, J.; Ullmann, A.; Ladant, D. A Bacterial Two-Hybrid System Based on a Reconstituted Signal Transduction Pathway. Proc. Natl. Acad. Sci. USA 1998, 95, 5752-5756. [CrossRef] [PubMed]

39. Malagon, F. RNase III Is Required for Localization to the Nucleoid of the $5^{\prime}$ Pre-RRNA Leader and for Optimal Induction of RRNA Synthesis in E. Coli. RNA 2013, 19, 1200-1207. [CrossRef]

40. Bartosik, A.A.; Mierzejewska, J.; Thomas, C.M.; Jagura-Burdzy, G. ParB Deficiency in Pseudomonas aeruginosa Destabilizes the Partner Protein ParA and Affects a Variety of Physiological Parameters. Microbiology 2009, 155, 1080-1092. [CrossRef] [PubMed]

41. Essar, D.W.; Eberly, L.; Hadero, A.; Crawford, I.P. Identification and Characterization of Genes for a Second Anthranilate Synthase in Pseudomonas aeruginosa: Interchangeability of the Two Anthranilate Synthases and Evolutionary Implications. J. Bacteriol. 1990, 172, 884-900. [CrossRef]

42. Steinegger, M.; Meier, M.; Mirdita, M.; Vöhringer, H.; Haunsberger, S.J.; Söding, J. HH-Suite3 for Fast Remote Homology Detection and Deep Protein Annotation. BMC Bioinform. 2019, 20, 473. [CrossRef]

43. Yang, J.; Anishchenko, I.; Park, H.; Peng, Z.; Ovchinnikov, S.; Baker, D. Improved Protein Structure Prediction Using Predicted Interresidue Orientations. Proc. Natl. Acad. Sci. USA 2020, 117, 1496-1503. [CrossRef] 
44. Katoh, K.; Standley, D.M. MAFFT Multiple Sequence Alignment Software Version 7: Improvements in Performance and Usability. Mol. Biol. Evol. 2013, 30, 772-780. [CrossRef]

45. Jones, D.T. Protein Secondary Structure Prediction Based on Position-Specific Scoring Matrices 1 1Edited by G. von Heijne. J. Mol. Biol. 1999, 292, 195-202. [CrossRef] [PubMed]

46. Holm, L. DALI and the Persistence of Protein Shape. Protein Sci. 2020, 29, 128-140. [CrossRef] [PubMed]

47. Baker, N.A.; Sept, D.; Joseph, S.; Holst, M.J.; McCammon, J.A. Electrostatics of Nanosystems: Application to Microtubules and the Ribosome. Proc. Natl. Acad. Sci. USA 2001, 98, 10037-10041. [CrossRef]

48. Bradford, M.M. A Rapid and Sensitive Method for the Quantitation of Microgram Quantities of Protein Utilizing the Principle of Protein-Dye Binding. Anal. Biochem. 1976, 72, 248-254. [CrossRef]

49. Lougheed, K.E.A.; Bennett, M.H.; Williams, H.D. An in Vivo Crosslinking System for Identifying Mycobacterial Protein-Protein Interactions. J. Microbiol. Methods 2014, 105, 67-71. [CrossRef]

50. Klockenbusch, C.; Kast, J. Optimization of Formaldehyde Cross-Linking for Protein Interaction Analysis of Non-Tagged Integrin $\beta$ 1. J. Biomed. Biotechnol. 2010, 2010, 1-13. [CrossRef] [PubMed]

51. Pfaffl, M.W. A New Mathematical Model for Relative Quantification in Real-Time RT-PCR. Nucleic Acids Res. 2001, 29 , e45. [CrossRef] [PubMed]

52. Andrews, S. FastQC: A Quality Control Tool for High Throughput Sequence Data 2010. Available online: http://www. bioinformatics.babraham.ac.uk/projects / fastqc (accessed on 8 June 2020).

53. Trapnell, C.; Roberts, A.; Goff, L.; Pertea, G.; Kim, D.; Kelley, D.R.; Pimentel, H.; Salzberg, S.L.; Rinn, J.L.; Pachter, L. Differential Gene and Transcript Expression Analysis of RNA-Seq Experiments with TopHat and Cufflinks. Nat. Protoc. 2012, 7, 562-578. [CrossRef]

54. Anders, S.; Pyl, P.T.; Huber, W. HTSeq-a Python Framework to Work with High-Throughput Sequencing Data. Bioinformatics 2015, 31, 166-169. [CrossRef] [PubMed]

55. Analyzing RNA-seq Data with DESeq2. Available online: https://bioconductor.org/packages/release/bioc/vignettes/DESeq2 /inst/doc/DESeq2.html (accessed on 8 June 2020).

56. Benjamini, Y.; Hochberg, Y. Controlling the False Discovery Rate: A Practical and Powerful Approach to Multiple Testing. J. R. Stat. Soc. Ser. B Methodol. 1995, 57, 289-300. [CrossRef]

57. Edgar, R. Gene Expression Omnibus: NCBI Gene Expression and Hybridization Array Data Repository. Nucleic Acids Res. 2002, 30, 207-210. [CrossRef] [PubMed]

58. Comparison of the Pseudomonas aeruginosa PA2504 Deficient Strain and the PAO1161 Wild Type Strain. Available online: https: / / www.ncbi.nlm.nih.gov / geo/query / acc.cgi?acc=GSE179150 (accessed on 1 July 2021). 